\title{
Medicinal plants and their validation challenges in traditional Egyptian medicine
}

\author{
Heba M. Amer ${ }^{*}$ iD, Ayman A. Mohammad² (D, \\ ${ }^{1}$ Medicinal and Aromatic Plants Research Department, National Research Centre, Giza, Egypt \\ ${ }^{2}$ Food Technology Department, National Research Centre, Giza, Egypt
}

\section{ARTICLE INFO \\ Received on: 15/06/2021 \\ Accepted on: 11/09/2021 \\ Available Online: 05/03/2022}

Key words:

Traditional medicine, authenticity, challenges, phytoconstituents, drug discovery.

\begin{abstract}
Remediation with medicinal herbal drugs is used in almost all cultures. Recently, herbal medicine has gained growing popularity in the current medical practice. The herbal products are considered available, acceptable, cheap, and safe products; thus, there is confidence in using these products. So, the quality, efficiency, and safety assurance of plant medicines became critical issues in both developed and developing countries. By standardizing the plant-derived drugs, a new era of a future remedy and healthcare system could be created. In order to keep this knowledge, historical records of medicinal plants are needed to be used for the benefit of humanity before their extinction forever. Egypt is characterized by a unique aromatic and medicinal flora that is required in the global market, which could increase the Egyptian exports. But there are several obstacles to the competition of Egyptian aromatic plants in the world market. Therefore, this review describes the historical use of medicinal plants throughout the published data using online search engines. The recent challenges in the quality, efficacy, authenticity, toxicity, and consistency of medicinal plants will be discussed. Also, this review aims to explore the economic situation and challenges of the herbal medicine industry in Egypt.
\end{abstract}

\section{INTRODUCTION}

Nature is the prominent source of symbiosis living phenomena. Traditional medicine mainly relies on ingredients extracted from natural resources such as herbs and animals, which have been used for the treatment of illnesses all over the world for a long time (Firenzuoli and Gori, 2007; Garg et al., 2021). Remediation utilizing traditional medicines is diminished within the developed countries. While almost $75 \%-80 \%$ of developing countries' populaces rely on traditional medication (Kamboj, 2000; Maroyi, 2013; Ozioma and Chinwe, 2019; WHO, 1995), the demand for traditional medicine in developing countries is increasing as the population grows especially plant-derived medicines. Interest in herbal medicine among pharmaceutical companies has also increased in developed countries (Hostettmann et al., 2000). On the other hand, the minor side effects of the

\section{*Corresponding Author}

Heba M. Amer, Medicinal and Aromatic Plants Research Department, National Research Centre, Giza,Egypt.E-mail:dr.heba_nrc@yahoo.com medicinal plants and the increasing prices of allopathic drugs, in addition to their failure to treat some diseases, led to the increase in traditional medicine consumption in the treatment of illness (Basgel and Erdemoglu, 2006).

Egyptian traditional medicine is characterized by a mixture that combines Arabic, Islamic, and African cultures. But, in the last decades, the use of herbal drugs in treatment has declined. Herbal therapeutics is practiced by a folk healer called "Attareens." They are unqualified people, but they have gained their experience from the Arab heritage, such as Avicenna and Dawood's ticket (Haggag, 2014). The author mentioned that the physicians, especially new graduates, neglect the description of herbal drugs to their patients. Physicians do not trust herbal drugs because they did not study their importance in their faculties. Actually, almost all medicinal faculties in Egypt lack courses that explain the value of herbal medicines. Therefore, doctors are not mindful of the significance of traditional therapy and its utilization by the Attareens. Also, the progress in organic chemistry resulted in the synthesis of numerous organic pharmacologically active compounds. The therapy with these compounds was encouraged 
by the ease of their laboratory synthesis in abundant quantities. In addition, the marketing promotions to these compounds by the producers play a crucial role in their use.

Now in Egypt, as in all over the world, people have become aware of the efficiency and safety of the herbal drug besides their lower cost. Now great efforts are made to study the Egyptian flora and discover new species. The studies include the most suitable pharmaceutical forms to be complementary to conventional drugs (not alternative medicines). The current strategy is to discover a compatible herbal drug with conventional medicine to make effective, safe, available, and affordable drugs (Abdel-Azim et al., 2011). Thus, this review summarizes and discusses the historical background, development, recent challenges, and future perspective of using herbal plants and their constituents. The obtained data reveal that Egyptian flora possesses a wide variety of traditional medicinal uses. Several active ingredients, for example, phenols, flavonoids, tannins, alkaloids, terpenes, saponins, steroids, and volatile oils, have been recognized. Although the activities of many herbal drugs in several traditional remediations have been evidenced, further investigation and validation of many other toxicological and biological studies are needed.

\section{HISTORY OF TRADITIONAL MEDICINE AND HERITAGE}

Herbal medicine therapy seems to be universal in successive civilizations, since its use dates back nearly 600 centuries in ancient Babylon, 50 centuries in Egypt and China, and 2.5 centuries in Central Asia and Greece. (Ang-Lee et al., 2001; Qazi and Molvi, 2016). The oldest book about herbal medicine in the world, "The Devine Farmer's Classic of Herbalism," was written in China 2000 years ago (Wachtel-Galor S and Benzie, 2011). However, the herbal systems, practices, and philosophy vary by the culture in which it first evolved (WHO, 2005). Chinese have their special herbal system recognized as the Traditional Chinese medicine (Wnag and Li, 2005). In India, Ayurveda, a healthcare system, has long been followed for over 50 centuries. Its materia medica describes over 1,500 herbal plants and 10,000 drug formulations (Goyal et al., 2012). Also, the Japanese herbal system, Kampo medicine, extended to 1,500 years with approximately 148 drug formulations (Watanabe et al., 2011).

The Arabs were subjected to Greek civilization for a long time before Islam and learned the hypothesis and practice of healing. Through the ages, the Persian Ibn-Sina, known as Avicenna, has been a great name in the history of medicine. Traditional medicine first came to the Persian Gulf through his writings (Moe et al., 2014). There are several Persian references for finding effective medicinal plants such as Canon, Al-Hawi fi al-tibb, and Tohfat al-Muaminin. The Canon book was authorized by Ibn-Sina and considered the reference of medicine for nearly 600 years (Ziaei et al., 2016). The second volume of the "Canon" book deals with medicinal plants' usage (Tashani and Johnson, 2010).

The book "Al-Hawi fi al-tibb" was written by Abu Bakr Muhammad ibn Zakariyya al-Razi based on his personal memoirs and notes. Al-Hawi is a genius work (23-volume series) that includes 900 case studies about disease treatments, with an emphasis on natural folk medicine and healing applications. Also,
Al-Hawi contains abstracts from preceding authors respecting various diseases and therapies (Savage-Smith, 1994). This book was translated into Latin in the 13th century and possessed a considerable influence over the European therapy medicament (Moe et al., 2014). The book "Tohfat al-Muaminin" is a comprehensive pharmacopeia of medicines written by the great pharmacist Hakim Muamin in the 16th century (Al-rhazes, 2005). This book is an important reference among the cohorts of folk medicine.

Traditional medicine has been used since the ancient ages for treating human illness in Egypt (Abdel-Azim et al., 2011; Haggag, 2014). Herbal medicine represents the main type of traditional medicine where the ancient Egyptians were experienced in medicinal herbs and their usefulness in the treatment of diseases. The first recorded prescriptions of herbal medicine were found in ancient Egyptian tombs (Mostafa and Singab, 2018). Moreover, the symbols on the temples' walls and writing in the papyri indicated that the Pharos was treated with several herbal medicines for the same purposes in a similar way as they are used today. Also, they applied their medicaments obtained from plant organs such as leaves, roots, fruits, flowers, rhizome, seed, and oils in the form of paste, cream, suppositories, pill, powder, and ointment (Dagmar, 2006; Shahat et al., 2001). It is enough to mention the amazing vague miracle of embalming. Nowadays, with tremendous scientific development, the mystery of embalming is still unknown. This indicated that the Egyptian herbal drugs were used on a scientific basis by a qualified herbalist who had the extensive knowledge to formulate the required drugs.

\section{HERBAL MEDICINES}

Herbal medicines are the prominent type of folk medicines, and in some cases, they are synonymous. Although they represent the oldest type of traditional medicine, they are still the widespread system of healthcare all over the world now. Herbal medicines are defined by World Health Organization (2000) as the herbs, herbal materials, herbal preparations, or finished herbal products in which the medicinally active ingredients obtained from aerial or underground parts of plants are intended to be used as therapeutics for human benefits and sometimes animal (Bent, 2008). Herbal drugs could include conventional excipients, naturally organic and inorganic compounds of nonvegetarian origin as well as vitamins and minerals in addition to the plant-based active ingredients. Herbal medicinal products may contain vitamins and minerals as supplementary substances. However, products to which synthetic compounds and/or isolated substances from herbal materials (Atropine and Diosgenin) have been added are not considered to be herbal medicinal products (Calixto, 2000).

The plants containing components that can be exploited for medicinal uses or potentially used for the synthesis of medicines are generally recognized as medicinal plants. These plants that have been exploited in folk healing for long times without scientific evidence to their efficiency are recognized as crude drugs of natural or organic origins. These plants could be further classified as "organized drugs" if they are originated in cellular plant parts such as roots, leaves, and steams and "unorganized 
drugs" if they are extracted from acellular parts of plants like oil, gums, gel, balsam, and exudate (Ozioma and Chinwe, 2019).

Plant parts used as herbal medicines are as follows (Ozioma and Chinwe, 2019):

- Roots: solid, fibrous, or fleshy parts of plant roots, for example, ginseng stinging nettle devil's claw roots.

- Bulbs: the structure that grows underground, for example, onions and garlic.

- Rhizome: the fleshy stems that grow horizontally underground while their leaves grow above the ground, for example, ginger, spear grass, and turmeric.

- Tubers: the swollen fleshy underground structures, for example, potatoes and yams.

- Bark: the outer layers that protect trunks or stems of the trees, for example, quinine bark, oak bark, pepper bark, and willow bark.
- Leave, stem, twigs, and buds of plants, shrubs, and trees, for example, maidenhair tree.

- Flower parts of several plants that have medicinal properties, for example, pyrethrum, saffron, santonica, clove, and chamomile.

- Seeds: seeds of several plants that have medicinal properties, for example, bitter almond, black mustard, cardamom, ispaghula, kaladana, linseed, and nutmeg.

- Fruits: fruits of several plants that have medicinal properties, for example, amla, anise, bael, bahera, bitter orange, capsicum, caraway, cardamom, colocynth, coriander, cumin, dill, fennel, star anise, and tamarind.

- Exudates, gum, and nectar parts which are formed by plants as self-defense agents against insects and animals, for example, acacia, guar gum, Indian gum, sterculia, and tra-gacenth.

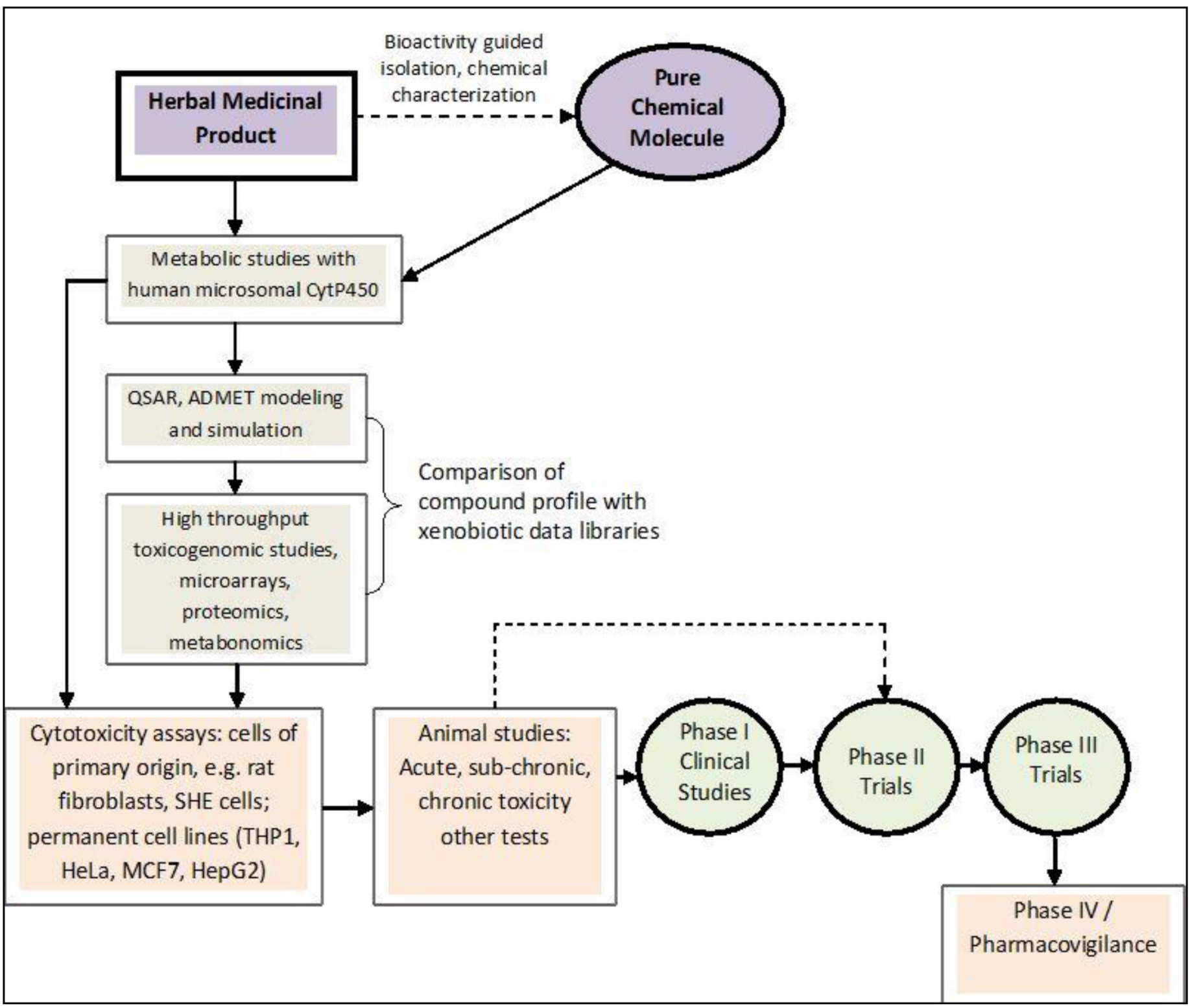

Figure 1. Schematic processes involved in evaluating and establishing the toxicity of medicinal herbs. The broken arrow indicates that this process for some herbal medicines may not always be necessary (source: Ifeoma and Oluwakanyinsola, 2013). 


\section{PROSPECTIVE CHALLENGES OF HERBAL MEDICINES USE}

\section{Toxicity and safety aspects}

Unlike allopathic medicines that include single or few standardized compounds, herbal medicine of a single plant contains hundreds of compounds that require a long time to be isolated and toxicologically assessed (WHO, 2005). In some countries, herbal products could be marketed without toxicological assessment. Moreover, these countries lack the ability to achieve such assessments (Ekor, 2014; Thakkar et al., 2020). Consequently, the lack of these aspects could expose the consumers to prospective hazardous and side effects due to the presence of toxic compounds (George, 2011; Mensah et al., 2019).

\section{Lack of quality control}

Quality control in the modern system of drugs production is of critical importance in order to justify its acceptability. Quality aspects of medicines include purity, identity, and safety assurance, in addition to efficiency of course. As a concern, the quality of herbal sources is a critical point facing herbal drug marketing (Verma and Singh, 2008). But, there are several challenging aspects involved in the quality standardization of medicinal and aromatic plants. These challenges include the temperature and light exposure, nutrients and water availability, and time and method of harvesting as well as postharvesting treatments, that is, drying, packing, storage, and transportation (Kunle et al., 2012).

\section{Lack of governmental legislation}

Herbal drugs can be marketed for maintaining, simulative, supportive, and promoting supplementary formulations healthcare and wellbeing in many countries. These formulations should have authenticity certificates labeled properly indicating the involved compounds and their intended medicinal purpose within humans according to Act 101 of 1965 and its amendments (2002) (Ndhlala et al., 2011). These labels evidenced the effectiveness, safety, and quality of such herbal medicines, thereby enhancing the concerns of consumer confidence in these herbal products (Ekor, 2014).

\section{Scientific and clinical assessment}

Unfortunately, not all naturally originated ingredients are safe. Some of the drugs used in traditional medicine proved to be harmful to some vital organs of the body. Therefore, quality, safety, and efficiency assurance of herbal products by researchers, regulatory authorities, and manufacturers must be achieved using comprehensive clinical trials and vital scientific methodologies, as illustrated in Figure 1 (Rana and Rana, 2014). The safety assessment of any medicinal compounds considers both the nature and significance of the adversary effects. WHO (2004) issued guidelines for assessing the safety of herbal medicine, which was followed by Food and Drug Administration (FDA), International Conference on Harmonization (ICH), and United States Pharmacopeia (USPC); these guidelines include the following:
- Clear drug botanical origin identification including extensive description of the basic botanical features, whether in the crude or processed forms.

- Complete ingredients identification through comprehensive chemical analysis, especially the pharmacologically active constituents using reliable estimating methods.

- Safety pharmacological comprehensive studies evaluating both acute and chronic toxicity.

- Efficiency confirmative clinical studies required for a drug. However, the long-run use of old drugs in several countries for the same disease treatment is good evidence of its efficiency.

\section{DRUG DISCOVERY OF NATURAL COMPOUNDS}

Natural drug discovery is a challenging task that describes the phytochemical analysis, characterization, and pharmacological investigation. It focuses on the process of finding and discovering new and effective drug compounds (Koparde et al., 2019). Various strategies for natural drugs discovery can be seen in Figure 2. Furthermore, herbal drug discovery could be classified into three stages, namely, predrug stage, quasidrug stage, and full-drug stage (Pan et al., 2013). Generally, the discovery processes of natural drugs could be classified into two major categories (Jamshidi et al., 2018).

\section{Traditional processes}

Figure 3 summarizes the traditional drug discovery process using the guided bioassay steps. The direct isolation process could lead to the isolation of several natural ingredients suitable for biological activity measurements. However, the discovery of herbal drugs and their identification was a difficult and lengthy process with a low rate of success and huge capital investment due to the complexity of the compounds (Barden and Weaver, 2010; Sarker and Nahar, 2013). Nowadays, the bioassay of herbal compounds is significantly improved by the innovation of precise methods and accurate techniques, that is, high-performance liquid chromatography (HPLC), liquid chromatography-mass spectrometry (LC/MS), gas chromatography-mass spectrometry (GC/MS), and nuclear magnetic resonance (NMR). These recent techniques are promising tools for the classification of compounds that are found in minor quantities in their origin (Koparde et al., 2019; Schroeder and Gronquist, 2006).

\section{Modern processes}

In modern pharmaceutical discovery research, new techniques, that is, combinatorial chemistry, HTS, bioinformatics, proteomics, and genomics, are widely emerging. These include molecular diversity, compound-library design, protein 3D structures, NMR-based screening, Three-dimensional quantitative structure-activity relationships (3D-QSAR) in modern drug design, physicochemical concepts, and computer-aided drug design using different software, its prediction of drug toxicity, and metabolism (Thomford et al., 2018). For instance, in the highthroughput screening (HTS) method, several molecules can be investigated in many quick assessments with minimum quantities of compounds. In HTS programs, a library of natural compounds should be established. These advanced techniques significantly improved the isolation and identification of natural products and 


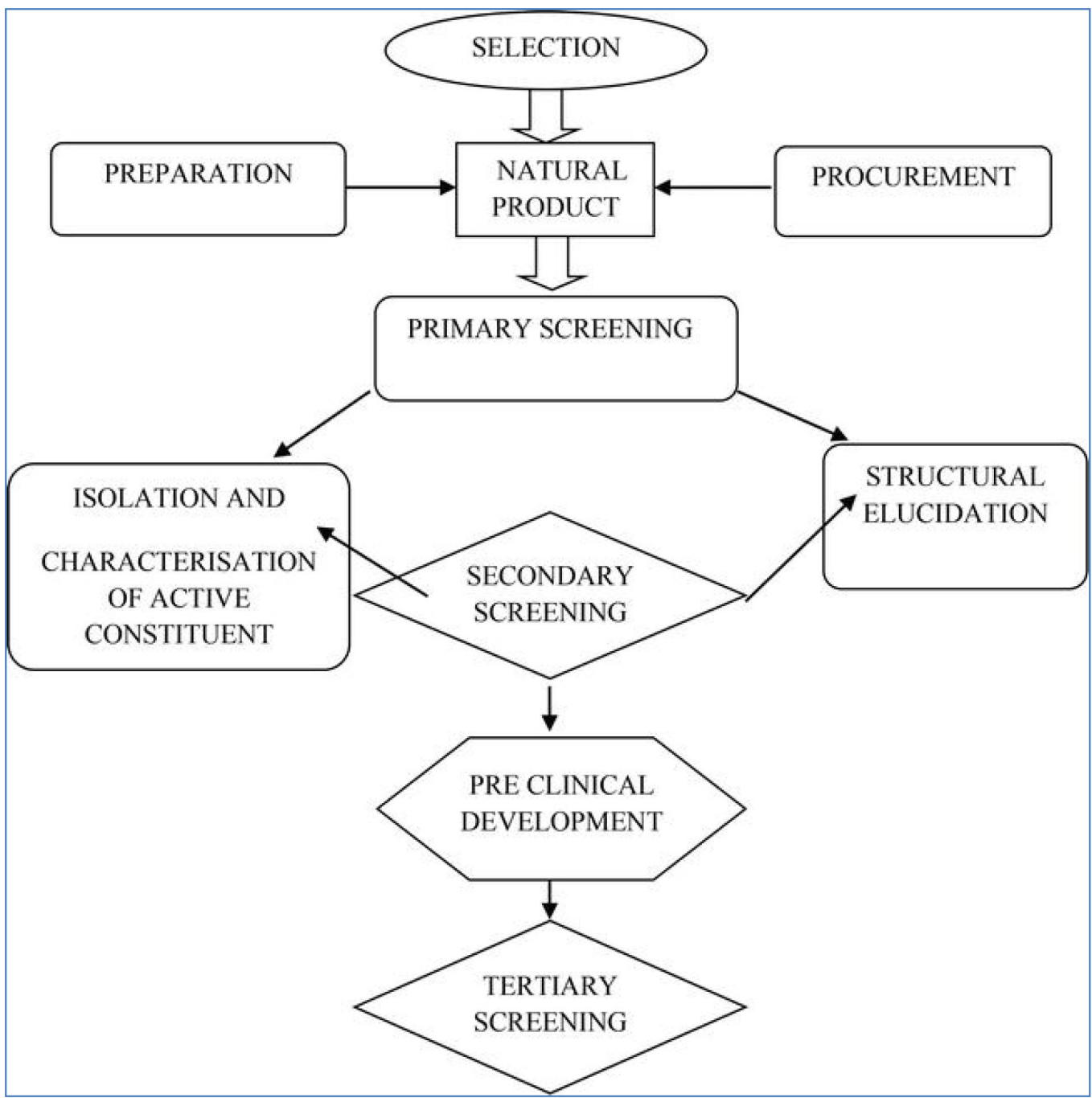

Figure 2. Various strategies for the discovery of drugs from natural resources (source: Koparde et al., 2019).

consequently enabled scientists to develop novel drug formulations (Fig. 4) (Sarker and Nahar, 2013).

\section{HERBAL MEDICINE IN EGYPT}

The Egyptian geographic position has made it a core of world trade since the beginning of creation. Egypt can be a pivot point in the field of herbal medicines in the Mediterranean and Arabia regions. Also, Egypt has wide areas of virgin land, free of contaminants and pollution, with its wide variety of climatic conditions that will ensure the high quality required for the products. Besides, Egypt owns the largest groups of experienced scientists able to deal with modern techniques. Egypt already has a strong infrastructure of low-cost factories of several other industries in the world market (Abdel-Azim et al., 2011). Besides, the Egyptian flora has more than 2,000 species of medicinal plants dispersed across the Egyptian locations. These locations vary in the edaphic and prevailing climatic and other ecological circumstances that encourage the growth of miscellaneous herbal species. Also, several herbal plants have been successfully adapted under the Egyptian condition (Shams et al., 2009).

\section{COMMON MEDICINAL PLANTS IN EGYPT}

Although many reports have clarified the Egyptian herbal plant for a long time, the comprehensive reporting of the Egyptian flora was prepared by Tackholm (1974). This report was revised, updated, and published in four series by Boulos $(1999,2000,2002,2005)$. This report indicated that herbal plants were and still are extensively used by the Egyptians for several ailments therapy. This encouraged the scientists to reconsider the old formulations (Abdel-Azim, 1998; Hamed et al., 2007; Mahmoud et al., 2007). Also, there is a general trend towards traditional therapy; consequently, herbal plants are proving to be unconventional drugs. Furthermore, numerous herbal medications are still used in folk medicine, and such products are distributed by herbal merchants all around Egypt.

For example, fennel, chamomile, basil, anise, peppermint (essential oils and aroma crops) are planted in Egypt with a very good reputation in the world trade. But the recent production characteristics of such products hinder their exportation due to the presence of improper contaminants levels and, in some cases, the presence of heavy metals, pesticides, and organic 


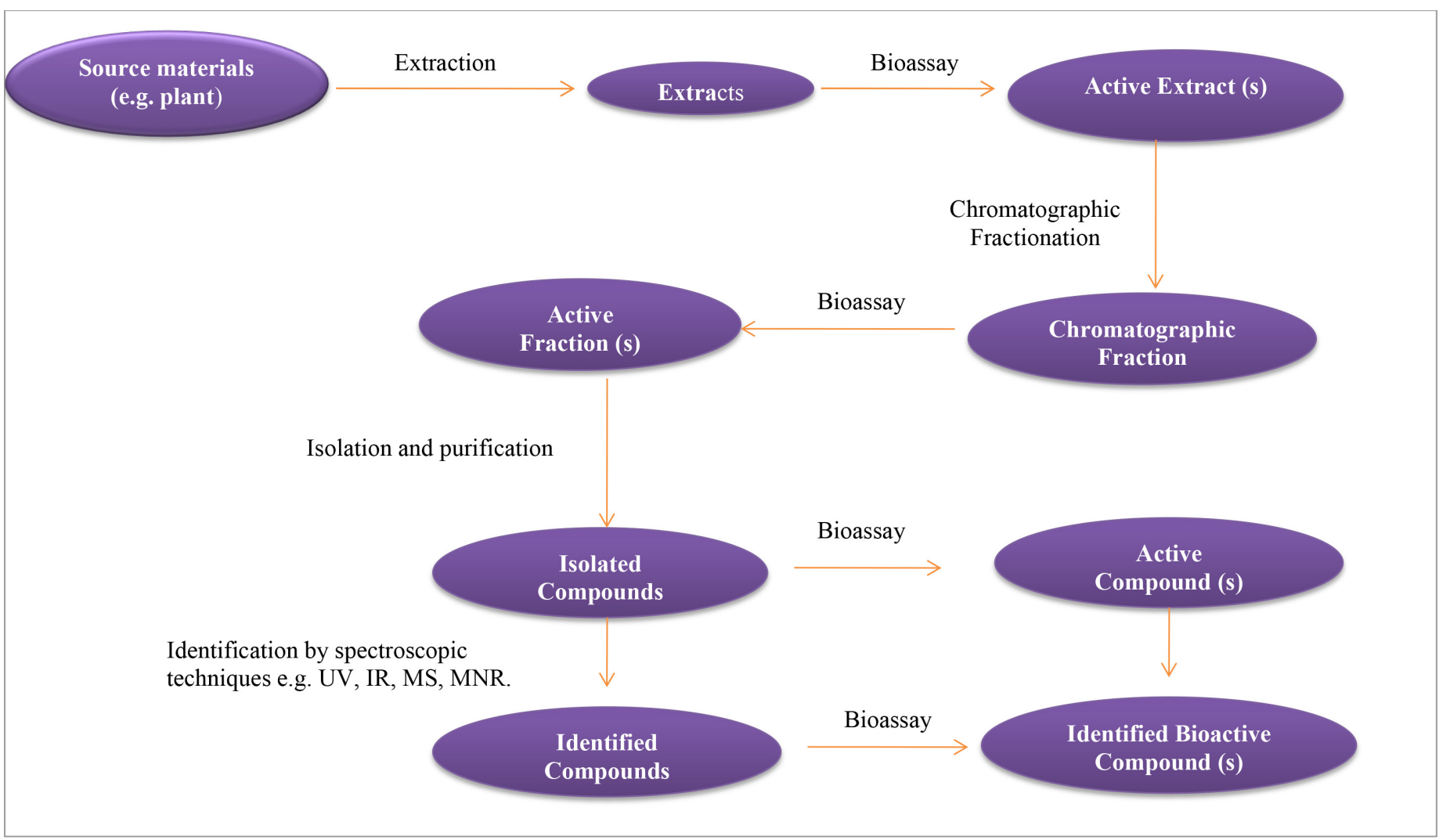

Figure 3. The traditional process of discovering natural drugs (source: Jamshidi et al., 2018).

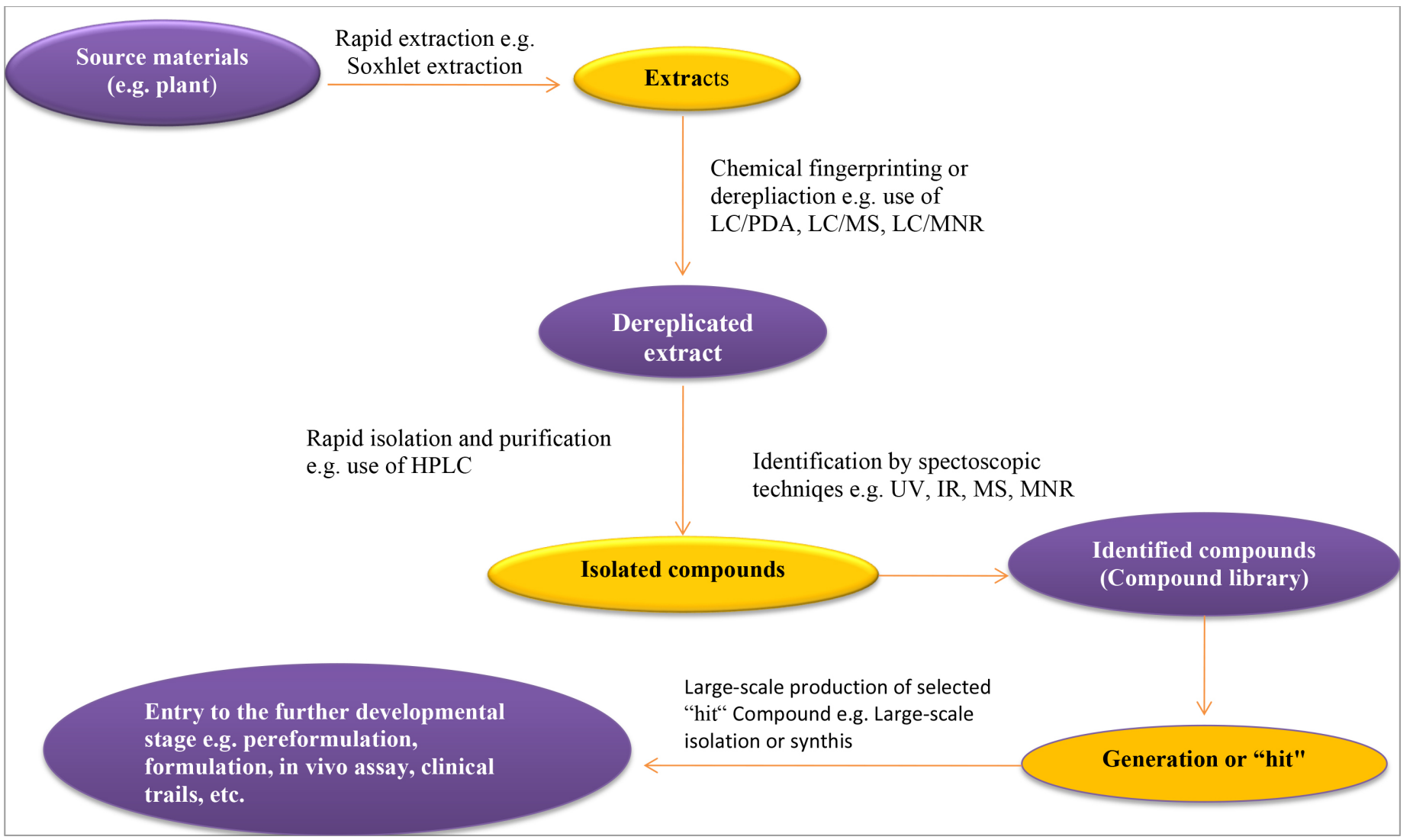

Figure 4. The modern process of discovering natural drugs (source: Jamshidi et al., 2018). 
Table 1. Validated medicinal plants and their medicinal uses.

\begin{tabular}{|c|c|c|c|c|}
\hline Name & Active compounds & Traditional use and validation & Used part & Dosage \\
\hline $\begin{array}{c}\text { Artemisia аппиа } \mathrm{L} \text {. } \\
\text { Family: Compositae } \\
\text { Common name: wormwood, } \\
\text { annual mugwort, and sweet annie }\end{array}$ & Artemisinin & $\begin{array}{l}\text { Antimalaria, hemorrhoids, and stomach } \\
\text { complaints (Yimer and Sahu, 2016) }\end{array}$ & Herb & 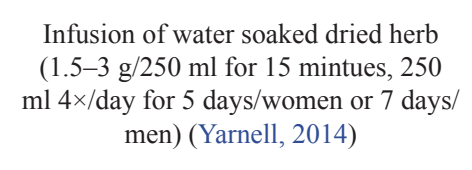 \\
\hline $\begin{array}{l}\text { Allium sativum } \\
\text { Family: Amaryllidaceae } \\
\text { Common name: garlic }\end{array}$ & $\begin{array}{l}\text { Alliin, allicin, ajoene, } \\
\text { amino acids, and selenium }\end{array}$ & $\begin{array}{l}\text { Coughs, chronic bronchitis, } \\
\text { bronchiticasthma, respiratory catarrh, } \\
\text { influenza, and cold } \\
\text { (Barnes et al., 2007) }\end{array}$ & Pulbs & $\begin{array}{c}\text { Adults: } 4 \mathrm{~g} \text { raw garlic/day (1-2 cloves)or } \\
300 \mathrm{mg} \text { dried garlic powder2-3 times per } \\
\text { day or } 7.2 \mathrm{~g} \text { per day(Bhandari, 2012) }\end{array}$ \\
\hline $\begin{array}{c}\text { Ginkgo biloba } \\
\text { Family: Ginkgoaceae } \\
\text { Common name: ginkgo, } \\
\text { maidenhair tree, and gingko }\end{array}$ & $\begin{array}{l}\text { Flavonol, flavone } \\
\text { glycosides, and } \\
\text { ginkgolides }\end{array}$ & $\begin{array}{l}\text { Improve circulation and cognition } \\
\text { (Boullata and Nace, 2000). } \\
\text { An expectorant, antitussive, } \\
\text { antiasthmatic, and memory impairment } \\
\text { (Barnes et al., 2007) }\end{array}$ & $\begin{array}{l}\text { Leaves and } \\
\text { seeds }\end{array}$ & $\begin{array}{l}50 \mathrm{mg} \text { three times daily/6 months } \\
\text { (Mullaicharam, 2013) }\end{array}$ \\
\hline $\begin{array}{c}\text { Eleutherococcus senticosus } \\
\text { Family: Araliaceae } \\
\text { Common name: Siberian } \\
\text { ginseng, eleuthero, and Devil's } \\
\text { shrub }\end{array}$ & $\begin{array}{l}\text { Eleutherosides, } \\
\text { ciwujianosides, and } \\
\text { eleutherans }\end{array}$ & $\begin{array}{c}\text { A general tonic, diabetes, } \\
\text { hypertension, and depression } \\
\text { (George, 2011) }\end{array}$ & Root & $\begin{array}{l}\text { Adults: } 10 \mathrm{ml} / 3 \text { times per day for } 21 \\
\text { days;300-400 mg daily for } 6-8 \text { weeks } \\
\text { (Brown, 2000) }\end{array}$ \\
\hline $\begin{array}{c}\text { Piper methysticum } \\
\text { Family: Piperaceae } \\
\text { Common name: Kava or kava } \\
\text { kava }\end{array}$ & Kavalactones & $\begin{array}{l}\text { Asthma, fever, syphilis, headaches, } \\
\text { rheumatism and gonorrhea, and urinary } \\
\text { infections (Barnes et al., 2007) }\end{array}$ & Rhizomes & $\begin{array}{c}\text { Typical usage has ranged from } 70 \text { to } 280 \\
\text { mg of kavalactones per day as one time } \\
\text { of day dose or divided doses ( } 60-120 \\
\text { mg of kavalactones per day). Several } \\
\text { practitioners allegedly begin at a lower } \\
\text { dose and measure up as needed (Ulbricht } \\
\text { et al., 2005) }\end{array}$ \\
\hline $\begin{array}{c}\text { Adiantum capillus-veneris L } \\
\text { Family: Pteridaceae } \\
\text { Common name: maidenhair fern, } \\
\text { venus hair fern }\end{array}$ & $\begin{array}{l}\text { Flavonoids, } \\
\text { triterpenoids, aoleananes, } \\
\text { phenylpropanoid, } \\
\text { carbohydrates, } \\
\text { carotenoids, and alicyclics }\end{array}$ & $\begin{array}{c}\text { Asthma, chest colds, } \\
\text { cough, edema, flu, and } \\
\text { urinary disorder (Mahmoud and } \\
\text { Gairola, 2013) }\end{array}$ & Herb & $\begin{array}{l}\text { The drug is taken internally as a tea } \\
\text { ready from the ground or fine-grained } \\
\text { drug. The customary single dose is } 1.5 \mathrm{~g} \\
\text { of the drug to one cup of liquid(Kirtikar } \\
\text { and Basu, 2003) }\end{array}$ \\
\hline
\end{tabular}

residues of extraction solvent (Abdel-Azim et al., 2011). Several pharmacological studies have established the medicinal uses of Egyptian plants. Among others, validated and invalidated medicinal plants and their uses are described in Tables 1 and 2, respectively.

\section{ECONOMIC VALUE OF MEDICINAL PLANTS IN EGYPT}

In the last three decades, herb and herbal product markets have shown extensive growth all over the world. According to the Secretariat of the Convention on Biological Diversity, world sales of herbal products totaled approximately US\$60 billion in 2002 (WHO, 2003). Nowadays, herbal plants in Egypt have become attractive and confident medicinal sources as alternative remedies. Recently, medicinal plants, herbal drugs, herbal drug-based medicaments, and natural herb production are growing industries in Egypt (Fabricant and Farnsworth, 2001). Besides, Egypt has agricultural traditions with the largest biodiversity. In addition, exports of Egyptian medicinal and aromatic plants all over the world have become a major business and important source of income (Abdel-Azim et al., 2011).

Egypt is one of the African exporter's leaders in the field of medicinal and aromatic plant trade. Furthermore, Egypt was the fifth biggest exporter of medicinal plants in the world since its medicinal plant exportation reached 11,250 tons/year (US\$12.35 million) in the period from 1992 to 1995 . In 1995, the annual export of perfumery, pharmaceutical, fungicidal and insecticidal plants was US\$13.79 million (Lange and Mladenova, 1997). But in 2002, the Egyptian exports of medicinal plants returned to the seventh place (WHO, 2003). Although Egypt has not recently been in the ranks of the major exporters of medicinal plants, Egypt is located in the markets of medicinal and aromatic plants worldwide, with a trade volume of more than 60 billion dollars annually, which is a major exporter of 158.94 million dollars (Abdel El-Hamid et al., 2019).

The Egyptian flora has over 150 medicinal and aromatic plants that are globally famous for their high quality. The main crops exported are mint (Mentha spp.), basil (Ocimum spp.), sage (Salvia spp.), plants for herbal teas, and plants utilized for perfumery, insecticidal, and fungicidal purposes. Egypt was the main exporter of German chamomile (Matricaria recutita L.). About 500 to 600 tons of Egyptian henbane (Hyoscyamus muticus L.) are exported annually to Germany. Wild and cultivated Alexandrian senna (Senna alexandrina Mill.) is also a significant export item (Vasisht and Kumar, 2004).

The aforementioned data revealed that the expanding interest in medicinal and aromatic plants, as new incomegenerating opportunities, is providing a complementary source of income for many extremely poor rural households. However, despite the fact that the medicinal and aromatic plants can have very high value in the final products, the farmer typically receives only a small share of the final value, either because they are unaware of the real value, unable to market it in the form wanted by consumers, or unable to market to these consumers. 
Table 2. Invalidated medicinal plants and their prospective medicinal uses.

\begin{tabular}{|c|c|c|c|c|}
\hline Name & Family & Local name & Used part & Traditional uses \\
\hline Aloe vera $\mathrm{L}$. & Aloaceae & Sabbar & Dried juice & Antidepressant, skin diseases, allergies, and headaches \\
\hline Atriplex sp. & Amaranthaceae & Liqatf & Whole plant & Treatment of diabetes mellitus and antioxidant activity \\
\hline Anacyclus pyrethrum & Asteraceae & Eaqir Qarhanaan & Roots & $\begin{array}{c}\text { Emmenagogue, vermifuge, febrifuge, memory-enhancing, and } \\
\text { antidepressant }\end{array}$ \\
\hline Artemisia Judaica & Asteraceae & Shayh Khursan & Whole plant & $\begin{array}{c}\text { Stomachic, expectorant, analgesic, diaphoretic, anthelmintic, } \\
\text { antispasmodic in case of intestinal colic and keeping snakes } \\
\text { away from houses, diabetic }\end{array}$ \\
\hline $\begin{array}{l}\text { Aerva javanica } \\
\text { (Burm.f.) Juss. }\end{array}$ & Amaranthaceae & Shajirat Alaru-Altaraf & Roots and leaves & Against rheumatism, antidiarrheal \\
\hline Amaranthus graecizans & Amaranthaceae & Alqatifuh & Leaves & Anthelmintic, constipation, treat tonsillitis \\
\hline $\begin{array}{l}\text { Brassica rapa subsp. } \\
\qquad \text { rapa }\end{array}$ & Brassicaceae & $\begin{array}{l}\text { Alshaljma-Allaft } \\
\text { Almahfur }\end{array}$ & Root & Antiscorbutic, aphrodisiac, hearing disorders \\
\hline Brassica nigra L. & Brassicaceae & Alkhardal & Seeds & $\begin{array}{l}\text { Alopecia, rheumatism and joint pains, toothache, and induration } \\
\text { of the liver and spleen }\end{array}$ \\
\hline $\begin{array}{l}\text { Balanites aegyptiaca } \\
\text { Del. }\end{array}$ & Balanitaceae & Alhijlij & Fruits & $\begin{array}{l}\text { Antidiabetic, epilepsy, wounds, malaria, syphilis, Anthelmintic, } \\
\text { dysentery, constipation, diarrhea, stomach, aches, asthma, fever, } \\
\text { and hemorrhoid }\end{array}$ \\
\hline $\begin{array}{l}\text { Calligonum } \\
\text { polygonoides }\end{array}$ & Polygonaceae & Artat mudlaea & Above ground part & Treatment of typhoid, eczema, cough and cold, asthma \\
\hline Cakile maritima & Brassicaceae & Kakil & Whole plant & Digestive, appetizing, diuretic and antiscorbutic \\
\hline Chenopodium murale & Chenopodiaceae & Zarbih & Above ground part & Intestinal tract pains and fever \\
\hline $\begin{array}{l}\text { Citrullus colocynthis } \\
\text { (L.) Schrad. }\end{array}$ & Cucurbitaceae & Hanzil-Ealqim & $\begin{array}{l}\text { Leaves, root, and } \\
\quad \text { fruit }\end{array}$ & $\begin{array}{c}\text { Diabetes, asthma, carminative and antiepileptic, toothache, } \\
\text { rheumatism, and } \\
\text { leprosy }\end{array}$ \\
\hline $\begin{array}{l}\text { Cleome droserifolia } \\
\text { (Forssk.) Delile }\end{array}$ & Capparaceae & Samuh & Leaves & Stomach ache, open wounds, diabetes, and skin allergies \\
\hline Cuscuta sp. & Convolvulaceae & Alkashkut & Seeds & Frequent urination, impotence, and premature ejaculation \\
\hline Cassia fistula $\mathrm{L}$. & Fabaceae & Khiar shambar & Fruits & Expectorant for brain and chest problems, detoxicant, tonic \\
\hline Euphorbia paralias L. & Euphorbiaceae & Labna & Whole plant & Anti-inflammatory, antitumor \\
\hline $\begin{array}{l}\text { Euphorbia granulate } \\
\text { Forssk. }\end{array}$ & Euphorbiaceae & Mlbanat-Haliba & Latex & $\begin{array}{l}\text { As sources of minerals for man and animals. Internally for } \\
\text { intestinal and externally for snake bites }\end{array}$ \\
\hline $\begin{array}{l}\text { Emblica officinalis } \\
\text { Gaertn }\end{array}$ & Euphorbiaceae & Amlaj & $\begin{array}{l}\text { Bark, dried fruit, } \\
\text { and leaves }\end{array}$ & $\begin{array}{l}\text { Laxative, stimulant, restoratives for all organs, anti- } \\
\text { inflammatory, analgesic, and antipyretic ophthalmic disorders }\end{array}$ \\
\hline $\begin{array}{l}\text { Ferula assa-foetida } \\
\text { Boiss. \& Bush. }\end{array}$ & Apiaceae & Hilatayt & Rhizome and root & $\begin{array}{c}\text { Strong nerve tonic, strong aphrodisiac, relieves ongoing mental, } \\
\text { stimulant, and joint inflammation }\end{array}$ \\
\hline $\begin{array}{l}\text { Lavandula } \\
\text { coronopifolia } \text { Poir. }\end{array}$ & Lamiaceae & Aldaram-Alafnadur & Leaves & Anti-inflammatory, hepatoprotective disorders, and stomach each \\
\hline $\begin{array}{l}\text { Imperata cylindrica }(\mathrm{L} .) \\
\text { Raeusch }\end{array}$ & Poaceae & Halfanaan & Rhizome flowers & Antipyretic, diuretic, hemoptysis, pulmonary diseases \\
\hline Malva parviflora $\mathrm{L}$. & Malvaceae & Alkhabizuh & $\begin{array}{l}\text { Leaves, root, and } \\
\text { flower }\end{array}$ & $\begin{array}{l}\text { Treatment of coughs and ulcers in the bladder, used to treat } \\
\text { wounds and swellings, for astringent properties, pyorrhea }\end{array}$ \\
\hline Nerium oleander L. & Apocynaceae & Tafaluh & Leaves & $\begin{array}{c}\text { Helping to wound healing, relieves knee and back pain and } \\
\text { cardiac illnesses and antidiabetic }\end{array}$ \\
\hline Nigella sativa & Ranunculaceae & $\begin{array}{l}\text { Habat Albarikata- } \\
\text { Alhubat Alsuwda }\end{array}$ & Seeds & $\begin{array}{c}\text { Digestive, analgesic, antihypertensive liver tonic, diuretic, } \\
\text { improving memory }\end{array}$ \\
\hline Peganum harmala & Zygophyllaceae & Harmal & Seeds & $\begin{array}{l}\text { Analgesic, treat depression, mental and nervous illnesses, and } \\
\text { hallucinogenic }\end{array}$ \\
\hline $\begin{array}{l}\text { Rosmarinus officinalis } \\
\text { L. }\end{array}$ & Lamiaceae & Aklil aljabal-Hasaliban & Arial parts & $\begin{array}{l}\text { Antidepressant, anxiety, analgesic in muscles and joints, poor } \\
\text { memory and diuretic and antispasmodic in renal colic }\end{array}$ \\
\hline Rharri partite (Ucria) & Anacardiaceae & Jadari & Fruits and leaves & Gastric, intestinal ailments \\
\hline Ruta graveolens L. & Rutaceae & Alsadhab & Leaves & $\begin{array}{l}\text { Dermatitis, pain and many inflammatory diseases, memory } \\
\text { enhancer, relieves strokes and rheumatism }\end{array}$ \\
\hline Salvia triloba & Lamiaceae & $\begin{array}{l}\text { Adhaanah qasir- } \\
\text { Marimih }\end{array}$ & Aerial parts & $\begin{array}{l}\text { Nerve tonic, anti-inflammatory, diarrhea, enteritis, and memory } \\
\text { enhancer }\end{array}$ \\
\hline Rumex vesicarius L. & Polygonaceae & Hamid & Leaves & $\begin{array}{l}\text { High content of oxalic acid, antitumor, constipation, bad } \\
\text { digestion, and appetizer }\end{array}$ \\
\hline Salvadora persica $\mathrm{L}$. & Salvadoraceae & Sawaak & $\begin{array}{l}\text { Roots, branches, } \\
\text { leaves, and fruit }\end{array}$ & $\begin{array}{l}\text { Analgesic, anticonvulsant, antimycotic, diuretic, carminative, } \\
\text { anti-inflammatory, bleeding and clotting time activities }\end{array}$ \\
\hline Echinacea purpurea & Asteraceae & Alakhnisia & Whole dried plant & $\begin{array}{l}\text { Antitoxin for snake bites, anti-inflammatory toothache, bowel } \\
\text { pain treating skin disorders, seizure, and cancer }\end{array}$ \\
\hline
\end{tabular}




\begin{tabular}{|c|c|c|c|c|}
\hline Name & Family & Local name & Used part & Traditional uses \\
\hline Salvia aegyptiaca L. & Lamiaceae & Alsilfiaa Almisrih & Above ground part & $\begin{array}{l}\text { Cicatrizant, Nervous disorders, dizziness, trembling, stomachic, } \\
\text { diarrhea, and strong antimicrobial and antioxidant effects }\end{array}$ \\
\hline Senna alexandrina Mill. & Fabaceae & Sinamiki & Leaves & $\begin{array}{c}\text { Anti-inflammatory, Parasite Cleaning stimulant laxative, bowel } \\
\text { evacuation }\end{array}$ \\
\hline Senna italic Mill. & Fabaceae & Alsanamikiu al'iitali & Leaves & $\begin{array}{c}\text { Stimulant laxative, bowel evacuation and antibacterial and } \\
\text { antitumor properties }\end{array}$ \\
\hline $\begin{array}{l}\text { Tamarix nilotica } \\
\text { (Ehrenb.) Bunge }\end{array}$ & Tamaricaceae & Tarafaan-Labe & Leaves & $\begin{array}{c}\text { Antiseptic, an antiseptic agent, Hemorrhoids, resting relieve } \\
\text { headache, draw out inflammation }\end{array}$ \\
\hline $\begin{array}{l}\text { Terminalia arjuna } \\
\text { (Roxb.) Wight \& Arn. }\end{array}$ & Combretaceae & Halij 'aswad & Fruits & $\begin{array}{l}\text { Heart diseases, skin diseases, improves memory and brain } \\
\text { function }\end{array}$ \\
\hline Tribulus terrestris L. & Zygophyllaceae & Aljaris & Fruits & $\begin{array}{l}\text { Diuretic, useful for asthma, cough, or cold. Natural nutritional } \\
\text { supplement, help impotence and heart disease }\end{array}$ \\
\hline Zilla spinosa (L.) Prantl & Brassicaceae & Alat-Shabaram & Whole dried plant & $\begin{array}{c}\text { Treat liver and kidney diseases, paralysis, diabetes, and urinary } \\
\text { tract diseases }\end{array}$ \\
\hline $\begin{array}{l}\text { Ziziphus spina-christi } \\
\text { L. Desf. }\end{array}$ & Rhamnaceae & Sdr-Nabaq & Leaves & $\begin{array}{l}\text { Colds, hypertension, astringent anthelmintic, antidiarrheal, and } \\
\text { demulcent }\end{array}$ \\
\hline $\begin{array}{l}\text { Zygophyllum coccineum } \\
\text { L. }\end{array}$ & Zygophyllaceae & Batibat & Fruits and seeds & $\begin{array}{c}\text { Anthelmintic, rheumatism, antipyretic, antihistamine, lowering } \\
\text { in blood pressure, and diuretic }\end{array}$ \\
\hline Zygophyllum simplex L. & Zygophyllaceae & Karamils & Leaves and seeds & $\begin{array}{l}\text { Anthelmintic, horny patches on the skin, and applied to eyes in } \\
\text { cases of ophthalmia and leucoma }\end{array}$ \\
\hline $\begin{array}{l}\text { Zingiber officinale } \\
\text { Roscoe }\end{array}$ & Zingiberaceae & Zanjibayls & Rhizome & $\begin{array}{l}\text { Osteoarthritis, joint inflammation, pain reliever, and rheumatoid } \\
\text { arthritis }\end{array}$ \\
\hline
\end{tabular}

\section{CHALLENGES OF EGYPTIAN MEDICINAL PLANTS}

The development and regulation of traditional medicines all over the world are often confronted with several challenges (Ekor, 2014). Regulatory status, efficacy assessment, quality control, safety monitoring, and inadequate or poor knowledge about traditional medicines within national authorities are common in many countries (WHO, 2005). Moreover, sharing the regulatory herbal medicines information between drug regulatory authorities and safety monitoring centers is an additional major challenge (WHO, 2004). From the economic point of view, in the developing countries, including Egypt, there are many challenges that prevent their entry into the global trade market and put them in a bad position (Samal et al., 2004). Regarding that, the traditional Egyptian medicines lack the following:

- Scientific evidence though well-documented efficacy and safety use with a proven scientific basis.

- Uniform quality standards of the collected material from different places of origin.

- The necessary information about the requirements of the international market and the technologies required to upgrade their produce.

- Intellectual Property Rights: extensive documentation to protect the traditional medicines from exploitation and biopiracy.

- Sustainable cultivation as well as postharvest and processing technologies.

- Value addition through processing into a more consumer useable form.

- Marketing strategies that make the grassroots level people have an equitable share in the profits.

\section{RECOMMENDATIONS FOR EGYPTIAN HERBAL MEDICINE DEVELOPMENT}

The future of Egyptian medicinal plants needs to develop the handling stages (e.g., cultivation, collection, processing, storage, marketing, and research), which should be encouraged by a proper guidelines framework to face the present challenges such as regulatory concerns, consumer perceptions, and competitions. Currently, the Egyptian producers of herbal plants need to consider the following areas to enter the global market:

- Cultivation of medicinal plants must be achieved in Good Agricultural Practice (GAP) and organic farming methods to ensure their safety. GAP includes comprehensive items such as ecological properties, locations, germplasm, cultivation, validation, identification of active compounds and metal elements, and pesticide detection.

- Advancing towards the isolation of pure bioactive compounds or substances, instead of the plant parts, with appropriate investigations of their activity and toxicity should be considered.

- Scientific researches and reliable data are required for the trusted use of herbal drugs in healthcare systems.

- The environmental ethics code should be considered to maintain the biodiversity of natural resources and prevent the loss of medicinal plant species due to high harvesting and destruction of habitats.

- The empirical guidelines should be replaced with evidencebased ones to increase the confidence use of herbal medicine through training the researchers and practitioners in the use of plant compounds.

- Finally, the aspects of efficiency, safety, acute and chronic toxicities, accurate dose, duration of treatment, side effects, and standardization of herbal drugs should be considered in order to achieve safe, effective, and affordable herbal drugs.

\section{CONCLUSION}

The demand for natural products has increased all over the world. In developing countries, about $85 \%$ of the people are treated with folk medicaments, especially herbal drugs. These demands are predominantly driven by the adverse effects of synthetic drugs. Therefore, the importance of medicinal plants has become significantly more than ever. More researchers are needed in the areas of the herbal plant through discovering new plants and drugs as well as phytochemical, biological, and clinical studies. Despite the long 
history of plant medicine use in folk healing systems, identification of active herbal ingredients can lead to discovering new prospective therapeutic uses and production of natural drugs. To perform these targets, great efforts should be made in the quality control of raw and formulated drugs to validate their use in the modern healthcare system. In this concern, biological and clinical studies are demanded to maximize the profits of these plants. In addition, a practical plan should be established to preserve the medicinal plants' resources. Medicinal plants are not only the sources of adjuvant diseases therapy but also for diseases prevention and maintaining health.

\section{AUTHOR CONTRIBUTIONS}

All authors made substantial contributions to conception and design, acquisition of data, or analysis and interpretation of data; took part in drafting the article or revising it critically for important intellectual content; agreed to submit to the current journal; gave final approval of the version to be published; and agree to be accountable for all aspects of the work. All the authors are eligible to be an author as per the international committee of medical journal editors (ICMJE) requirements/guidelines.

\section{FUNDING}

There is no funding to report.

\section{CONFLICT OF INTEREST} interest.

All authors have declared that they have no conflict of

\section{ETHICAL APPROVALS}

This study does not involve experiments on animals or human subjects.

\section{DATA AVAILABILITY}

All data generated and analyzed are included within this research article.

\section{PUBLISHER'S NOTE}

This journal remains neutral with regard to jurisdictional claims in published institutional affiliation.

\section{REFERENCES}

Abd El-Hamid A, Mohamed NS, Makled SM, Abd Elmonem S. Determinants of production and export for some medicinal and aromatic plants in Egypt. Arab Univ J Agric Sci, 2019; 27(2):1351-69.

Abdel-Azim NS, Shams KA, Shahat AA, El Missiry MM, Ismail SI, Hammouda FM. Egyptian herbal drug industry: challenges and future prospects. Res J Med Plant, 2011; 5:136-44.

Abdel-Azim, NS. A cardnolide glycoside from Gomphocarpus sinaicus. Phytochemistry, 1998; 49:273-5.

Al-rhazes (Rhazes) M. Persian translation by S. Afsharipour Academy of Medical Sciences Publication, Tehran, Iran, 2005. Al Havi (Liber Continent).

Ang-Lee MK, Moss J, Yuan CS. Herbal medicines and perioperative care. JAMA, 2001; 286:208-16.

Barden CJ, Weaver DF. The rise of micropharma. Drug Discov Today, 2010; 15:84-7.

Barnes J, Anderson LA, Phillipson JD. Herbal Medicine. 3rd edition, Pharmaceutical Press, London, UK, 2007.

Basgel S, Erdemoglu SB. Determination of mineral and trace elements in some medicinal herbs and their infusions consumed in Turkey. Sci Total Environ, 2006; 359:82-9.
Bent S. Herbal medicine in the United States: review of efficacy, safety, and regulation. J Gen Intern Med, 2008; 23:854-9.

Bhandari PR. Garlic (Allium sativum L.): a review of potential therapeutic applications. Int J Green Pharm, 2012; 118:129.

Boullata JI, Nace AM. Safety issues with herbal medicine. Pharmacotherapy, 2000; 20:269-57.

Boulos L. Flora of Egypt. Al-Hadara Publishing, Cairo, Egypt, vol. 1, 1999. vol. 2, 2000.

Boulos L. Flora of Egypt. Al-Hadara Publishing, Cairo, Egypt, vol. 3, 2002 vol. 4, 2005 .

Boulos L. Flora of Egypt. Al-Hadara Publishing, Cairo, Egypt,

Boulos L. Flora of Egypt. Al-Hadara Publishing, Cairo, Egypt,

Brown DJ. Herbal prescriptions for healing and health. Prima Publishing, Roseville, CA, 2000.

Calixto JB. Efficacy, safety, quality control, marketing and regulatory guidelines for herbal medicines (phytotherapeutic agents). Braz Asian J Med Biol Res, 2000; 33:179-89.

Dagmar L. International trade in medicinal and aromatic plants. Actors, volumes and commodities plants. In: Bogers RJ, Craker LE, Lange D (eds.). Medicinal and aromatic plants, Springer, New York, NY, pp 15570, 2006.

Ekor M. The growing use of herbal medicines: issues relating to adverse reactions and challenges in monitoring safety. Front Pharmacol, 2014; 4:1-10

Fabricant DS, Farnsworth NR. The value of plants used in traditional medicine for drug discovery. Environ Health Perspect, 2001; 109:69-75.

Firenzuoli F, Gori L. Herbal medicine today: clinical and research issues. Evid Based Complement Alternat Med, 2007; 4(Suppl 1):37-40.

Garg AK, Faheem M, Singh S. Role of medicinal plant in human health disease. Asian J Plant Sci Res, 2021; 11(1):19-21.

George P. Concerns regarding the safety and toxicity of medicinal plants - an overview. J Appl Pharm Sci, 2011; 1:40-4.

Goyal M, Sasmal D, Nagori BP. Ayurveda the ancient science of healing: an insight. In: Vallisuta O, Olimat SM (eds.). Drug discovery research in pharmacognosy, InTech Open, Croatia, Balkans, pp 1-10, 2012.

Haggag MY. Herbal medicine in Egypt. Iran J Pharm Res, 2004 3(Suppl 2):5-6.

Hamed AR, Abdel-Shafeek KA, Abdel-Azim NS, Ismail SI, Hammouda FM. Chemical investigation of some Capparis species growing in Egypt and their antioxidant activity. Evid Based Complement Altern Med, 2007; 4:25-8.

Hostettmann K, Marston A, Ndjoko K, Wolfender JL. The potential of African plants as a source of drugs. Curr Org Chem, 2000; 4:973-1010.

Ifeoma O, Oluwakanyinsola S. Screening of herbal medicines for potential toxicities. New insights into toxicity and drug testing. InTech, Croatia, Balkans, vol. 244, pp 63-88, 2013.

Jamshidi F, Lorigooini Z, Amini-Khoei H. Medicinal plants: past history and future perspective. J Herbmed Pharmacol, 2018; 7:1-7.

Kamboj VP. Herbal medicine. Curr Sci, 2000; 78:35-9.

Kirtikar KR, Basu BD. Indian medicinal plants with illustration. 2nd edition, International Book Distributors, Dehradun, India, pp 3747-9, 2003.

Koparde AA, Doijad RC, Magdum CS. Natural products in drug discovery, pharmacognosy-medicinal plants. In: Perveen S, Al-Taweel, A (eds.). IntechOpen, 2019. Available via https:/www.intechopen.com/books/ pharmacognosy-medicinal-plants/natural-products-in-drug-discovery

Kunle OF, Egharevba HO, Ahmadu PO. Standardization of herbal medicines - a review. J Biodivers Conserv, 2012; 4:101-12.

Lange D, Mladenova M. Bulgarian model for regulating the trade in plant material for medicinal and other purposes. In: Bodeker G, Bhat KKS, Burley J, Vantomme P, (eds.). Medicinal plants for forest conservation and health care, non-wood forest products, FAO, Rome, Italy, pp 135-46, 1997. 
Mahmoud SM, Abdel-Azim NS, Shahat AA, Ismail SI, Hammouda FM. Phytochemical and biological studies on Verboscum sinaiticum benth growing in Egypt. Nat Prod Sci, 2007; 12:186-9.

Mahmoud T, Gairola S. Traditional knowledge and use of medicinal plants in the Eastern Desert of Egypt: a case study from Wadi El-Gemal National Park. J Med Plants Stud, 2013; 1:10-7.

Maroyi A. Traditional use of medicinal plants in south-central Zimbabwe: review and perspectives. J Ethnobiol Ethnomed, 2013; 9:31.

Mensah ML, Komlaga G, Forkuo AD, Firempong C, Anning AK, Dickson RA. Toxicity and safety implications of herbal medicines used in Africa. Herb Med, 2019; 63:1992-0849.

Moe T, Al Obaidly FA, Al Khoder R, Schmid D. Folk medicine and integrative healing in West Asia: analysis of historical and modern practice and perceptions. Avicenna, 2014; 2014:1-13.

Mostafa NM, Singab AN. Prospective of herbal medicine in Egypt. Med Chem, 2018; 8:116-7.

Mullaicharam ARA. Review on evidence based practice of Ginkgo biloba in brain health. Int J Chem Pharm Anal, 2013; 1:24-30.

Ndhlala AR, Stafford GI, Finnie JF, Staden JV. Commercial herbal preparations in KwaZulu-Natal, South Africa: the urban face of traditional medicine. "South Afr J Bot, 2011; 77:830-43.

Ozioma EOJ, Chinwe OAN. Herbal medicines in African traditional medicine. Herb Med, 2019; 10:191-214.

Pan S, Zhou S, Gao S, Yu Z, Zhang S, Tang M, Sun J, Ma D, Han

Y, Fong W, Ko K. New perspectives on how to discover drugs from herbal Medicines: CAM's Outstanding contribution to modern therapeutics. Evid Based Complement Alternat Med, 2013; 627375:1-25.

Qazi MA, Molvi K. Herbal medicine: a comprehensive review. J Pharm Res, 2016; 8:1-5.

Rana KK, Rana S. Review on present status and future of herbal medicine. Beats Nat Sci, 2014; 1:1-8.

Samal, PK, Shah A, Tiwari SC, Agrawal DK. Indigenous healthcare practices and their linkage with bioresource conservation and socio-economic development in Central Himalayan region of India. Indian J Tradit Knowl, 2004; 3:12-26.

Sarker SD, Nahar L. Chemistry for pharmacy students: general, organic, and natural product chemistry. John Wiley Sons Inc, pp 1-383, 2013.

Savage-Smith E. Islamic culture and medical arts. National Library of Medicine, Bethesda, MD, 1994.

Schroeder FC, Gronquist M. Extending the scope of NMR spectroscopy with microcoilprobes. Angew Chem Int Ed Engl, 2006; 45:7122-31.

Shahat AA, Pieters L, Apers S, Nazeif NM, Abdel-Azim NS, Berghe DV, Vlietinck AJ. Chemical and biological investigations on Zizyphusspina-christi L. Phytother Res, 2001; 15:593-7.

Shams K, Nazif N, Azim N, Shafeek K, Missiry M, Ismail S, Nasr M. Isolation and characterization of antineoplastic alkaloids from Catharanthus roseus 1. Don. cultivated in Egypt. Afr. J. Trad. CAM, 2009; $6: 118-22$

Tackholm V. Student's flora of Egypt. Cairo University Press, Cairo, Egypt, 1974

Tashani OA, Johnson MI. Avicenna's concept of pain. Libyan J Med, 2010; 5:5253-9.

Thakkar S, Anklam E, Xu A, Ulberth F, Li J, Li B, Hugas M, Sarma N, Crerar S, Swift S, Hakamatsuka T. Regulatory landscape of dietary supplements and herbal medicines from a global perspective. Regul Toxicol Pharmacol, 2020; 114:104647.
Thomford NE, Senthebane DA, Rowe A, Munro D, Seele P, Maroyi A, Dzobo K. Natural products for drug discovery in the $21 \mathrm{st}$ century: innovations for novel drug discovery. Int J Mol Sci, 2018; 19:1-29.

Ulbricht C, Basch E, Boon H, Ernst E, Hammerness P, Sollars D. Safety review of kava (Piper methysticum) by the Natural Standard Research Collaboration. Expert Opin Drug Saf, 2005; 4:779-94.

Vasisht K, Kumar V. Compendium of medicinal and aromatic plants, Africa. ICS-UNIDO, Trieste, Italy, 2004.

Verma S, Singh SP. Current and future status of herbal medicines. Vet World, 2008; 1:347-50.

Wachtel-Galor S, Benzie IFF. Herbal medicine. In: Benzie I, Wachtel-Galor S (eds.). Herbal medicine: biomolecular and clinical aspects, 2nd edition, CRC Press/Taylor \& Francis, Boca Raton, FL, 2011.

Watanabe K, Matsuura K, Gao P, Hottenbacher L, Tokunaga H, Nishimura K. Traditional Japanese Kampo medicine: clinical research between modernity and traditional medicine - the state of research and methodological suggestions for the future. Evid Based Complementary Altern Med, 2011; 2011:1-19.

WHO. Traditional practitioners as primary health workers: guidelines for training traditional health practitioners in primary health care. World Health Organisation, Geneva, Switzerland, 1995.

WHO. General guidelines for methodologies on research and evaluation of traditional medicine. World Health Organization, Geneva, Switzerland, 2000.

WHO. WHO guidelines on good agricultural and collection practices (GACP) for medicinal plants. World Health Organization, Geneva, Switzerland, 2003.

WHO. WHO guidelines on safety monitoring of herbal medicines in pharmacovigilance systems. World Health Organization, Geneva, Switzerland, 2004.

WHO. National policy on traditional medicine and regulation of herbal medicines. World Health Organization, Geneva, Switzerland, 2005.

Wnag S, Li Y. 2005. Trdaitiional Chinese medicine. In: Devinsky $\mathrm{O}$, Schachter S, Pacia S (eds.). Complementary and alternative therapies for epilepsy, Demos Medical Publishing, New York, NY.

Yarnell E. Artemisia annua (Sweet Annie), other artemisia species, artemisinin, artemisinin derivatives, and malaria. J Rest Med, 2014; 3(69):84.

Yimer S, Sahu O. Traditional medicines for treatment African diseases by Artemisia annua. Med Sci Pub Health, 2016; 4:22-32.

Ziaei A, Sahranavard S, Faizi M. Topical herbal remedies for treatment of joint pain according to Iranian Traditional Medicine. Res J Pharm, 2016; 3:63-72.

How to cite this article:

Amer HM, Mohammad AA. Medicinal plants and their validation challenges in traditional Egyptian medicine. J Appl Pharm Sci, 2022; 12(03):023-033. 